\title{
A CAPACIDADE PATRIMONIAL NA FAMILIA ROMANA PECULIA E PATRIA
} POTESTAS

\author{
THE PATRIMONIAL CAPACITY IN FAMILIA ROMANA - PECULIA AND PATRIA POTESTAS
}

\section{Rodrigo de Lima Vaz Sampaio**}

\begin{abstract}
Resumo:
O peculium é compreendido como um patrimônio de risco do filiusfamilias e sua história relacionada tanto com a existência de serviços, como de atividades das pessoas submetidas ao paterfamilias. Por meio das características do peculium profecticium e das relações com os demais peculia, é possível analisar a familia romana como uma unidade econômica, administrativa e política. Este estudo no campo do Direito Privado Romano pode também ser um caminho para se entender a familia como seminarium rei publicae, ou seja, como origem da República.
\end{abstract}

Palavras-chave: Familia. Patria potestas. Peculia. Peculium Profecticium. Seminarium rei publicae.

\begin{abstract}
:
The peculium is understandable as a risk patrimony of the filiusfamilias, and your history is related to the existence of services as far as of activities from people subjected to the paterfamilias. By means of the features of the peculium profecticium and of the relationships with the others peculia, it is possible to analyse the familia romana as a economical, administrative and political unity. The present study in the field of Roman Private Law can also be a path to understand the familia as seminarium rei publicae, that is, as the beginnen of the Republic.
\end{abstract}

Keywords: Familia.Patria potestas. Peculia.Peculium Profecticium. Seminarium rei publicae.

1. Peculium Profecticium no Binômio "Sujeição-Independência" do Filiusfamilias

Em regra, ao se falar de patria potestas e de peculium, a atenção volta-se, quase que automaticamente, aos seus representantes mais conhecidos: peculium castrense,

\footnotetext{
Intervenção realizada no XIII Congreso Internacional y XVI Congreso Iberoamericano de Derecho Romano - O Direito de Família, de Roma à Atualidade (seus Anais, p. 103-128).

** Doutorando em Direito Civil e Romano pela Faculdade de Direito da Universidade de São Paulo, sob orientação do Professor Titular Eduardo Cesar Silveira Vita Marchi. Diplomado no Corso di Alta Formazione in Diritto Romano 2010-2011 da Università degli Studi di Roma I - "La Sapienza". Graduado cum laude pela Faculdade de Direito da Universidade de São Paulo, em 2009.
} 
ou militare, ${ }^{1}$ quasi castrense ${ }^{2}$ e adventicium. ${ }^{3}$ Porém, existe outro caminho que pode e deveria ser percorrido um maior número de vezes, já que ajuda a compreensão de categorias jurídicas relevantes: o estudo do peculium profecticium, que cria um "patrimônio de risco" nas mãos do filiusfamilias (de agora em diante, com devidas alterações, apenas "filius") e constitui o parâmetro para os demais peculia.

\footnotetext{
FITTING, Hermann. Das Castrense Peculium in seiner Geschichtlichen Entwicklung und heutigen gemeinrechtlichen Geltung (1871). Amsterdam: Scientia, 1969. p. 11-13 (= §2). Augusto concede aos soldados, ainda submetidos à patria potestas, e para os quais não existia a possibilidade de realizar um testamento, a autorização de validamente o fazer, com o que se obtém com exercício militar - "in castris", ou seja, lucros, saques de guerra e donativos (Inst. 2, 12 pr. e UE 20, 10). LA ROSA, Francia. I peculii speciali in diritto romano. Milano: Giuffrè, 1953. p. 5, considera este um momento de singular importância, o que, pode ser explicado, entre outros motivos, pelo fato que, segundo TALAMANCA, Mario. Istituzioni di diritto romano. Milano: Giuffrè, 1990. 122, esse peculium é moldado em oposição ao peculium profecticium, o que é vital para a compreensão do(s) diálogo(s) entre pecunia e patria potestas.

Cf. também FUMAGALLI, Marcella Balestri. Persone e famiglia nel diritto romano. Digesto delle Discipline Privatistiche - Sezione Civile, Torino, v. 13, 1995. p. 453; e GUARINO, Antonio. Diritto privato romano (1971). 12. ed. Napoli: Jovene, 1988. p. 544-545 (= § 40).

2 FUMAGALLI, Marcella Balestri. Persone e famiglia ... cit. (nota 1), p. 453-454. Talvez com Constantino, o reconhecimento vá além do peculium castrense aos filiifamilia miles: o peculium quasi castrense, literalmente, "pecúlio como se fosse militar". FITTING, Hermann. Das Castrense Peculium cit. (nota 1), p. 388-390 (= §54), explica que, a rigor, ao se acrescentar "quasi" ao lado de uma palavra, essa é utilizada com um significado que não lhe seria próprio. De fato, o peculium quasi castrense engloba todos os bens adquiridos no exercício de um cargo burocrático, da advocacia, ou no serviço eclesiástico. Enfim, qualquer atividade da "militas civilis" [GUARINO, Antonio. Diritto privato romano cit. (nota 1), p. $545(=\S 40)$ ]. Não se tardará para a admissão, no século II d.C., que os filiifamilia tenham plena capacidade jurídica sobre peculi especiais, podendo dispor inter vivos ou mortis causa. Dentre as fontes, em especial, Inst. 2, 11, 6 . Principalmente, sobre as demais fontes que fazem comparação entre peculia castrense e quasi castrense, cf. FITTING, Hermann. Das Castrense Peculium. cit. (nota 1), p. 390 (=§54), e, sobre peculium quasi castrense, ARCHI, Gian Gualberto. In tema di peculio quasi castrense. In: Studi di Storia e Diritto in Onore di Enrico Besta per il XL Anno del Suo Insegnamento. Milano, Giuffrè, 1939. v. 1, p. 119-136.
}

3 Sobre o peculium adventicium, cf. item II, infra. 
Como diminutivo de pecúnia, ${ }^{4}$ peculium ${ }^{5}$ é usado esporadicamente tanto como sinônimo de patrimonium, ${ }^{6}$ quanto de Sparpfennig $^{7}$ [= "poupança"].

Mas, em sentido original, uma vez que o patrimonium é um todo unitário, a quintessência do peculium é corresponder a um ou mais pedaços isolados deste, ou seja, "ein Sondergut" [= "bem especial/ particular"]. ${ }^{8}$ Sobretudo, nesta acepção, peculium

4 UXKULl-GYLlenBAND, Woldemar Graf von. Peculium. Paulys - Wissowa Realencyclopädie der classischen Altertumswissenschaft, Weimae, Stuttgart, v. 19-1, 1937. p. 13. Derivado do coletivo "pecus" [= "bétail", "Vieh", "gado/ bois"], pecunia era o nome da "moeda" entre os latinos, fazendo referência ao antigo uso de pagar com gado o valor das mercadorias (Varr. Ling. lat., 5, 19 e 95; Colum. Re rust., 6; e Fest. Verb. sig., "abgregare": "abgregare est ab grege ducere: adgregare ad gregem ducere: segregare ex pluribus gregibus partes seducere, unde et egregius dicitur e grege lectus. Quorum verborum frequens usus non mirum si ex pecoribus pendet, quum apud antiquos opes et patrimonia ex his praecipue constiterint, ut adhuc etiam precunias et peculia dicimus"). Em seguida, os metais, além de seu caráter mais funcional, representariam um valor para as trocas, e, assim, "pecunia" e "peculium" teriam perdido o sentido "unidade de troca". Desta forma, também "peculium", ao início, referia-se concretamente ao rebanho de bois deixados sob a guarda de um servus, e, depois, sofre uma abstração, passando ao sentido de "pecúlio" como "conjunto de riquezas" (juridicamente atestado em Ulp. 29 ad ed. D. 15, 1, 5, 3, "pusilla pecunia").

"Pecunia", por outro lado, ao menos no Baixo Império, ganha o sentido especial de "moedas de cobre", (HA - Alex. Sev., 33, 3: "scaenicis numquam aurum, numquam argentum, uix pecuniam donauit"). Assim, três são as fases de evolução da palavra "peculia": "riqueza em bois" (concretos), depois "moedas" (Eutr. $9,14)$ e, depois, "moedas de cobre".

O antigo sistema monetário teria como unidades "bois" e "ovelhas", sendo que um boi equivaleria a dez ovelhas, como, mais tarde, na Escandinávia, uma vaca a dez ovelhas. Os antigos bairros romanos eram

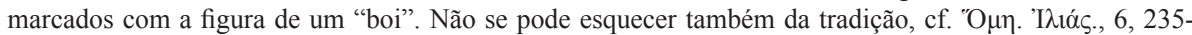
236, pela qual as armas de ouro de Glauco e de bronze de Diomedes tinham, por valor, respectivamente, cem e nove bois. Também se pode perceber que, entre todos os povos de origem ariana, e as diferentes línguas que derivam dessa família, existem palavras semelhantes à "pecunia": "fee", do inglês, significa "salário", derivado do anglo-saxão "feoh", "boi", e a identidade da origem do gótico "skatta", e do anglosaxão "sceat", "moeda", ou , do antigo eslavo "skotu" e do irlandês "scath", "rebanho". Cf. BERGER, Adolf. Encyclopedic Dictionary of Roman Law. Clark: Lawbook, 1953. p. 624; e LENORMANT, François. Pecunia, In: DAREMBERG, Charles; SAGLIO, Edmond (org.). Dictionnaire des Antiquités Grecques et Romaines. Graz: Akademische, 1963. t. 4, p. 369-370.

Ainda, HEUMANN, Hermann Gottlieb, e SECKEL, Emil. Handlexikon zu den Quellen des römischen Rechts. 9. ed. Jena: Fischer, 1907. p. 413, quanto à presença de "pecunia" nas antigas formulae da mancipatio e do testamento; ERNOUT, Alfred; MEILLET, Antoin. Dictionnaire étymologique de la langue latine - Histoire des mots. 4. ed. Paris: Klincksieck, 1979. p. 492; HEINRICHS, Johannes. Peculium. Der neue Pauly - Enzyklopädie der Antike, Weimar, v. 9, 2000, p. 462; e STUMPF, Gerd. Pecunia. Der neue Pauly - Enzyklopädie der Antike, Weimar, v. 9, 2000, p. 462.

5 Ulp. 29 ad ed., D. 15, 1, 5, 3: "Peculium dictum est, quasi pusilla pecunia sive patrimonium pusillum" [= "Denomina-se pecúlio, por assim dizer, uma pequena fortuna ou um pouco de patrimônio"]. Cf., também, nota 22 , infra.

6 HORAT. Ars poet. 330-332 [“(...) an, haec animos aerugo et cura peculi cum semel imbuerit, speramus

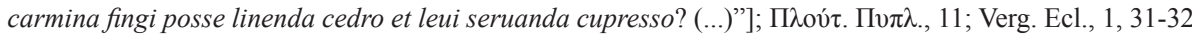
["namqu - fatebor enim - dum me Galatea tenebat, nec spes libertatis erat nec cura peculi"]; e também em CIL 12, 1005, onde na sétima e oitava linha de uma inscrição encontrada na Gallia Narbonensis, atual Languedoc e Provence, aparece a expressão "cvrator pecvlii r(ei) p(ublicae)". Também HEUMANN, Hermann Gottlieb; SECKEL, Emil. Handlexikon. cit. (nota 4), p. 412, e as seguintes fontes jurídicas: Ulp. 29 ad ed., D. 15, 1, 5, 3; Ulp. 4 fideic., D. 36, 1, 17 pr.; e Valent., Theod. et Arc. C. 12, 57, 7, 2 [= 389 d.C.].

7 Sen. Ben., 7, 4, 4; Cels. 9 dig., D. 32, 1, 79 ["peculium appellantes, quod praesidii causa seponeretur" (= "entende-se por pecúlio o que é excluído por precaução")].

8 Este seria o sentido mais técnico e estrito da palavra, cf. HEUMANN, Hermann Gottlieb; SECKEL, Emil. Handlexikon cit. (nota 4), p. 412. Por exemplo, Liv. 2, 41; e D. 15, 1. 
é o Sondergut que o paterfamilias ("pater") entrega livremente a um subiectus, para sua administração e exploração. ${ }^{9}$ Em outras palavras, concede um empréstimo "zu irgendeinem Unternehmen" [= "para um empreendimento qualquer"], confia a ele um "Gewerbebetrieb" [= "firma de negócios"], ${ }^{10}$ ou simplesmente entrega, por exemplo, coisas, terrenos, escravos, e/ou gado. ${ }^{11}$

Neste sentido, dois são os atributos que qualificam o peculium: uniformidade, ou homogeneidade, e autonomia, ou independência. ${ }^{12}$

Atualmente, a terminologia "Sondergut" aparece no BGB, com destaque para a disciplina do regime de bens. O § 1417, diz "(1) Vom Gesamtgut ist das Sondergut ausgeschlossen; (2) Sondergut sind die Gegenstände, die nicht durch Rechtsgeschäfte übertragen werden kommen; (3) Jeder Ehegatte verwaltet sein Sondergut selbständig. Er verwaltet es für Rechnung des Gesamtguts". Também aparece, entre outros, nos $\S \S 1440$ (Haftung für Vorbehalts- oder Sondergut) e 1486 (Vorbehaltsgut; Sondergut).

Sobre a utilização de "peculium" no mecanismo "genus-species", cf. TALAMANCA, Mario. Lo schema 'genus-species' nelle sistematiche dei giuristi romani, in La filosofia greca ed il diritto romano. In: Colloquio italo-francese. Roma, Accademia Nazionale dei Lincei, 1977. v. 2, p. 269.

9 UXKULL-GYLLENBAND, Woldemar Graf von. Peculium cit. (nota 4), p. 13.

10 BERGER, Adolf. Encyclopedic Dictionary cit. (nota 4), p. 624. Esta concessão para um empreendimento poderia ser tanto comercial, como industrial.

11 UXKULL-GYLLENBAND, Woldemar Graf von. Peculium cit. (nota 4), p. 13. Ele admite a concessão, por meio de peculium, de coisas incorpóreas, por exemplo, um crédito frente a terceiro. Em sentido contrário, mas em referência à opinião de Labeão e Pompônio de que o peculium seria "ein Komplex körperlicher Sachen", em Ulp. 29 ad ed., D. 15, 3, 3, 5, cf. TUHR, Andreas von. Actio de in rem verso zugleich ein Beitrag zur Lehre von der Geschäftsführung. Freiburg: Akademische, 1895. p. 267.

Sobre isso, GLÜCK, Christian Friedrich. Ausführliche Erläuterung der Pandecten nach Hellfeld: ein Commentar. Erlangen: Palm, 1813. v. 14, p. 357-360 (= § 905), diz que o peculium é uma "universitas iuris", o que compreenderia, como uma herança, todos os gêneros de objetos, não somente móveis e imóveis, mas também bens incorpóreos, como créditos (Ulp. 29 ad ed., D. 15, 1, 7, 4). Além disso, pode aumentar ou diminuir, sendo que o valor pago por uma coisa determinará contra quem a actio de peculio será conferida, ou seja, ela não se volta propriamente contra quem administra o peculium, mas sim contra quem recebe o valor pago pela coisa. Neste sentido, Jav. 12 ex Cass., D. 15, 1, 33; Pomp. 12 ex var. lect., D. 15, 1, 34; Marc. 5 reg., D. 15, 1, 40; Ulp. 12 ad ed., D. 15, 1, 42; e Paul. 2 ad Ner., D. 17, 1, 61. Cf., também, RODGER, Alan Ferguson. Peculium. The Oxford Classical Dictionary. 3. ed. London: Oxford University, 2003. p.1130. Exata a definição de peculium é dada por HEINRICHS, Johannes. Peculium cit. (nota 4), p. 462: "Der Begriff p. bezeichnet das Sondervermögen einer Person, die nach röm. Recht fremder Gewalt unterworfen war: meist eines Haussohns in der - patria potestas oder eines Sklaven im Besitz des - dominus."; e interessante a de MANDRY, Gustav. Das gemeine Familiengüterrecht mit Ausschluss des ehelichen Güterrechtes. Tübingen: Laupp, 1876. v. 2, p. $6(=\S 53)$ : "Peculium ein Vermögen ist, weiterhin dass dieses Vermögen einen Bestandtheil des Patrimonium bildet, endlich dass es thatsächlich und nur thatsächlich Vermögen der gewaltunterworfenen Person ist."

12 UXKULL-GYLLENBAND, Woldemar Graf von. Peculium cit. (nota 4), p. 13. MICOLIER, Gabriel. Pécule et capacité patrimoniale - Étude sur le pécule, dit profectice, depuis l'édit "de peculio" jusqu'à la fin de l'époque classique. Lyon: BOSC, 1932. p. 187, destaca que o caráter homogêneo do peculium dentro do patrimonium do pater sempre existe, mesmo que seus elementos ativos e passivos variem. Sob essa perspectiva, o peculium aparece como uma universitas iuris, que se distingue, ao mesmo tempo, dos conjuntos não unificados de bens ou de direitos e dos corpora ex distantibus. Mas, quando se submete a um ato de transferência, a título particular, o peculium perderia sua coerência, pois aproxima-se desta última categoria. Assim, três seriam as regras quanto a essa característica: formar um grupo homogênio dentro do patrimonium do pater; constituir uma abstração, já que seria independente dos elementos que o compõe; e perder a coesão quando ocorrer um ato de disposição. 
É justamente a esse instituto que se relaciona a evolução mais significativa do regime patrimonial não só a que o filius ${ }^{13}$ era submetido, mas também a própria família. ${ }^{14}$

Embora a patria potestas signifique uma sujeição mais ampla do filius ao poder pessoal do pater, ${ }^{15}$ que, a princípio, era caracterizado essencialmente pelo ius vitae ac necis [= "direito de vida e de morte"], não se deve espantar, em um primeiro momento, que a relação entre pater e filius fosse comparada, se não considerada semelhante, àquela entre dominus e servus. ${ }^{16}$

Para Marcella Balestri Fumagalli, ${ }^{17}$ este é um princípio que se torna quase “incomprensibile”, já que, no Direito Público, o alieni iuris era plenamente capaz. Percepção que acentua com o tempo, pois o antigo princípio civilístico que equipara o filius ao servus quanto à absoluta incapacidade patrimonial - "qui in potestate nostra est, nihil suum habere potest"18 - continuaria, ao menos em teoria, em vigor, no período justinianeu.

13 MARRONE, Matteo. Istituzioni di diritto romano (1989). 2. ed. Firenze: Palumbo, 1994. p. 246-248 (= $\S$ 98). Ele precisa que filius juridicamente são, seja homens, seja mulheres, aqueles efetivamente filhos do paterfamilias, ou que foram por ele adotados (adrogatio ou adoptio), e ainda os seus netos(as), e assim por diante. Todos eram, assim, considerados, nessa cadeia, filius, mas a posição deles, mais próximos ou distantes do pater, apresenta uma importância, em primeiro lugar, no momento da extinção da potestas, mas também no procedimento da adoptio ou emancipatio.

14 FUMAGALLI, Marcella Balestri. Persone e famiglia cit. (nota 1), p. 453. Sobre comparação entre mulier e filius, do ponto de vista patrimonial, cf., entre outros, TALAMANCA, Mario. In tema di azioni di arricchimento. Archivio Giuridico "Filippo Serafini", Modena, v. 146, 1954, p. 33-74.

15 Observar que os poderes inerentes à patria potestas não podem mudar seja a liberdade, seja a cidadania do filius. Cf. VOLTERRA, Edoardo. Famiglia (diritto romano). Enciclopedia del Diritto, Milano, v. 16, 1967. p. 742.

Deve-se também lembrar de Siete Partidas 4, 17 pr. e 1 ("Del poder que han los padres sobre los fijos, de qual natura quier que sean"), ou seja, tanto sobre filhos legítimos (Siete Partidas 4, 13), como ilegítimos (Siete Partidas 4, 15), respectivamente: "Poder et señorio han los padres sobre los fijos segunt razon natural et segunt derecho: lo uno porque nascen dellos, et lo al porque han de heredar lo suyo. Onde pues que en el título ante deste fablamos de los fijos legitimos et de todos los otros, de qual natura quier que sean, queremos aqui decir deste poderio que han los padres sobrellos: et mostrar qué cosa es: et en quántas maneras se puede entender esta palabra: et como debe seer establescido: et qué fuerza ha" e "Qué cosa es el poder que ha el padre sobre sus fijos et sobre sus nietos - Patria potestas en latin tanto quiere decir en romance como el poder que han los padres sobre los fijos: et este poder es un derecho atal que han señaladamiente los que viven et se judgan segunt las leyes antiguas derechas que fecieron los filósofos et los sabior por mandado et por otorgamiento de los emperadores: et hanlo sobre sus fijos, et sobre sus nietos et sobre todos los otros de su linage, que descenden dellos por la liña derecha, et que son nascidos del casamiento derecho".

16 Uma comparação que aparece nitidamente na definição de HEINRICHS, Johannes. Peculium cit. (nota 4), p. 462 , nota 11 , supra.

17 FUMAGALLI, Marcella Balestri. Persone e famiglia. cit. (nota 1), p. 453. Essa antiga regra significaria que os filii podem realizar qualquer ato jurídico, desde que com exclusiva vantagem ao pater e pelo ius honorarium (esses debita serão considerados, pelo ius civile, obligationes naturales, relevantes, no plano jurídico, principalmente pela soluti retentio). Mas, também cf. MARRONE, Matteo. Istituzioni cit. (nota 13), p. 248 (= § 98), para o qual a sujeição não significava que, uma vez adulto, o filius (varão) não adquirisse plena capacidade de direito público, podendo votar nas assembléias populares, serem eleitos como magistrados e senadores, e, depois, ocupar cargos imperiais. E também, sejam os filii, como as filiae, poderiam se casar, bastando o consenso inicial do pater.

18 Gai. 2, 87. Cf., também, ALVES, José Carlos Moreira. Direito romano: instituições de direito romano parte especial - direito das obrigações - direito de família - direito das sucessões (1965). 6. ed. Rio de 
Por outro lado, Roberto Pesaresi ${ }^{19}$ mostra que o peculium é também um meio com o qual o filius, ou o servus, é comparado com o pater, uma vez que seria "velut proprium patrimonium". ${ }^{20}$

Essa submissão, mais bem traduzida pelo binômio "sujeição-independência", quanto ao peculium, pode encontrar seu início em um conjunto de bens conferidos inicialmente apenas pelo pater - "peculium profecticium" [= "pecúlio profectício"], ou seja, "peculium a patre profectum" [= "pecúlio que provem do pai", ou seja, que parte de uma iniciativa paterna]. ${ }^{21}$

Difundido desde o período pré-clássico, esse pequeno conjunto de bens "pusilla pecunia"22 - era concedido ao filius, tendo em vista suas necessidades pessoais, e, às vezes, não sendo essa concessão secreta, para o exercício de uma atividade industrial ou comercial. ${ }^{23}$

A submissão do filius e dos servi à potestas mostrava que o subiectus não era proprietário, nem possuidor legítimo dos bens, mas tinha somente "eine tatsächliche

Janeiro: Forense, 2005. v. 2, p. 268 (= n. 277).

19 PESARESI, Roberto. Ricerche sul peculium imprenditoriale. Bari: Cacucci, 2008. p. 15-17.

20 Flor. 11 inst., D. 15, 1, 39. Cf., também, Paul. 4 ad Plaut., D. 15, 1, 47, 6 [“(...) quasi patrimonium liberi hominis peculium servi intellegitur (...)"]. Como patrimônio "separatum" da res domini, cf. Pomp. 7 ad Sab., D. 15, 1, 32 pr.; Ulp. 29 ad ed., D. 15, 1, 5, 4; e Jul. 44 dig., D. 41, 1, 37, 1. Ademais, cf., sobre a elaboração jurisprudencial sobre o peculium, Amirante, Luigi. Lavoro di giuristi sul peculio - Le definizioni da Q. Mucio a Ulpiano. In: Studi in Onore di Cesare Sanfilippo. Milano: Giuffrè, 1983. v. 3, p. 3-15.

${ }_{21}$ Guarino, Antonio. Diritto privato romano. cit. (nota 1), p. $543(=\S 40)$; Fumagalli, Marcella Balestri. Persone e famiglia. cit. (nota 1), p. 453, fala em "quasi a patre profectum"; MARRONE, Matteo. Istituzioni. cit. (nota 13), p. 248 (=§ 98); e GIRARD, P. F. Manual élémentaire de droit romain. 8. ed. Paris: Arthur Rousseau, 1929. p. 151

Cf., também, GLÜCK, Christian Friedrich. Ausführliche Erläuterung der Pandecten nach Hellfeld: ein Commentar. Erlangen: Palm, 1800. v. 2, p. 253 (= § 136), para quem “das peculium profectitium die Natur des alten Peculiums behalten habe".

Segundo BONFANTE, Pietro. Corso di Diritto Romano - diritto di famiglia. Milano: Giuffrè, 1963. v. 1, p. 138, a terminologia "peculium profecticium" seria conferida pelos autores modernos, com base naquela romana da "dos profecticia" (o que encontra nas fontes um paralelo entre dos adventicia e peculium adventicium). Cf. Jav. 1 epist., D. 42, 5, 28, e item I, in fine.

A prática de entregar ao filho uma pequena quantidade de bens é atestada também por LANFRANCHI, Fabio. Il diritto nei retori romani - Contributo alla storia dello sviluppo del diritto romano. Milano: Giuffrè, 1938. p. 282, em Sen. Contr., 3, 3: "Cum tricenario filio pater patrimonium dividat".

22 Ulp. 29 ad ed., D. 15, 1, 5, 3. Sobre o texto, cf. AMIRANTE, Luigi. Lavoro di giuristi. cit. (nota 20), p. 3-15. Ulpiano define como "pusilla pecunia" ou "patrimonium pusillum", mas existe também, nas fontes, a definição de Tuberão, jurista da época de César, acolhida por Celso, jurista do tempo de Adriano, para os quais o peculium é "quod servus domini permissu separatum a rationibus dominicis habet, deducto inde si quid domino debetur" (Ulp. 29 ad ed., D. 15, 1, 5, 4). Por esta, existem duas contas ou registros patrimoniais: aquela do pater, a ratio dominica, e outra representada por tudo aquilo que for da primeira separada (caráter residual), e que configuraria o peculium. E, nessa definição, aparece o antigo princípio, talvez anterior a Sérvio Sulpício Rufo, de subtrair, do valor do peculium, as dívidas do escravo com o dominus. Princípio retomado em outras fontes, principalmente em Ulp. 29 ad ed., D. 15, 1, 9, 2-3.

23 GUARINO, Antonio. Diritto privato romano. cit. (nota 1), p. 543-544 (= § 40). LA ROSA, Francia. I peculii speciali. cit. (nota 1), p. 5-7, explica que aos poucos alguma atividade econômica deveria ser concedida ao filius. Esse peculium era administrado "con ampi poteri" pelo filius por meio do conceito de administratio. Sobre administratio, cf. item II, infra. 
Detention" [= "uma detenção efetiva/real"], uma vez que era somente um "Verwalter des peculium" [= "administrador do peculium" $].{ }^{24}$

Mas o peculium profecticium nunca deixava de ser um fato absolutamente interno na familia. Em outras palavras, o filius realizava sua administratio nos limites fixados pelo pater, sendo que este, por ser titular dos direitos - proprietário - sobre as res peculiares, responde pelos atos daquele. ${ }^{25} \mathrm{E}$, neste sentido, seu fundamento estaria em Pomp. 7 ad Sab., em D. 15, 1, 4 pr. ${ }^{26}$

E, assim, indiretamente, o ius honorarium, por meio da criação da actio de peculio [= "ação sobre o pecúlio"] ${ }^{27}$ faria com que o pater respondesse apenas nos estritos limites em que o peculium foi concedido, e o próprio filius, quando tomava decisões autônomas, seria "trattato in certo qual modo come titolare giuridico del peculium stesso". ${ }^{28}$

Entretanto, o detentor do peculium, ou melhor, do e sobre o peculium, precisava, para nascer, de uma concessio [= "concessão"] do pater, a qual poderia ser revogada a qualquer momento. E, neste sentido, a frase de Woldemar Graf von UxkullGyllenband: "Inhaber, sondern ist ein Bestandteil des väterlichen Vermögens" [= "Detentor, mas antes é um elemento do patrimônio do pater"]. ${ }^{29}$

24 UXKULL-GYLLENBAND, Woldemar Graf von. Peculium. cit. (nota 4), p. 13-14. Assim, o que o subiectus ganha com a administratio do peculium pertence necessaria e juridicamente ao pater. No mesmo sentido, GLÜCK, Christian Friedrich. Ausführliche Erläuterung. II. cit. (nota 21), p. 254 (= § 136), que fala em "körperlichen Besitz", "posse do corpo/ detenção". Curiosamente, Gaudemet, Jean. Droit privé romain. Paris: Montchrestien, 1998. p. 211, diz que o pater permanece apenas "théoriquement" dono do peculium. Outros, ao invés de "detenção", falam em "posse". Cf. nota 39, infra.

25 GUARINO, Antonio. Diritto privato romano. cit. (nota 1), p. $544(=\S 40)$.

26 "Peculii est non id, cuius servus seorsum a domino rationem habuerit, sed quod dominus ipse separaverit suam a servi rationem discernens: nam cum servi peculium totum adimere vel augere vel minuere dominus possit, animadvertendum est non quid servus, sed quid dominus constituendi servilis peculii gratia fecerit." Também, cf. UXKULL-GYLLENBAND, Woldemar Graf von. Peculium. cit. (nota 4), p. 14.

27 Gai. 4, 72a, "Est etiam de peculio et de in rem uerso actio a praetore constituta. Licet enim negotium ita gestum sit cum filio seruoue, ut neque uoluntas neque consensus patris dominiue interuenerit, si quid tamen ex ea re, qua cum illis gesta est, in rem patris dominiue uersum sit, quatenus in rem eius uersum fuerit, eatenus datur actio. Versum autem quid sit, eget plena interpretatione. At si nihil sit uersum, praetor dat actionem, dumtaxat de peculio, et edictum utitur his uerbis. Quod edictum loquitur et de eo, qui dolo malo peculium ademerit. Si igitur uerbi gratia ex HS. X, quae seruus tuus a me mutua accepit, creditori tuo HS. V soluerit, aut rem necessariam, puta familia cibaria, HS. V emerit et reliqua V quolibet modo consumpserit, pro $V$ quidem in solidum damnari debes, pro ceteris uero eatenus, quatenus in peculio sit. Ex quo scilicet apparet, si tota HS. X in rem tuam uersa fuerint, tota HS. me consequi posse ..."; C. 4, 26 ("Quod cum eo qui in aliena est potestate negotium gestum esse dicitur, vel de peculio seu quod iussu aut de in rem verso"); Inst. 4, 7, 4-4c; além, obviamente, de D. 15, 1-3.

28 GUARINO, Antonio. Diritto privato romano. cit. (nota 1) p. 544 (= $\$ 40)$. Em sentido oposto, LA ROSA, Francia. I peculii speciali. cit. (nota 1), p. 5-7, segundo o qual esse patrimonium apenas estava "di fatto" sob o poder do filius, tanto que o pater responderia, dentro do prazo de um ano, pela actio de peculio pelos atos daquele, mesmo se estes não se relacionam diretamente com o peculium. Cf., também, UXKULLGYLLENBAND, Woldemar Graf von. Peculium. cit. (nota 4), p. 13-14.

29 UXKULL-GYLLENBAND, Woldemar Graf von. Peculium. cit. (nota 4), p. 14. Também sobre o "domini permissu", Paul. 54 ad ed., D. 41, 2, 1, 5. Cf. BESELER, Gerhard. Beiträge zur Kritik der römischen Rechtsquellen. Tübingen: MOHR, 1920. v. 4, p. 63, e . Textkritische Studien. Zeitschrift der Savigny- 
Topograficamente, o peculium vem tratado em D. 15, $1 .^{30}$ A matéria essencialmente é a actio de peculio, pela qual tanto o pater, em relação ao filius, como

Stiftung für Rechtsgeschichte - Romanistische Abteilung, Weimar, v. 53, 1933. p. 25, onde afirma que, em Marc. 5 reg., D. 15, 1, 40, 1, "dis Shilderung der nativitas peculii ist unsinnig und töricht".

Em um momento posterior, a permissão do pater seria somente indispensável, se o peculium fosse ampliado por ação do próprio pater. A ideia de concessio peculii - Ulp. 29 ad ed., D. 14, 6, 3, 2; Jul. 12 dig., D. 15, 1, 37, 1; Ulp. 26 ad ed., D. 12, 6, 3 pr.; e Pomp. 15 ad Sab., D. 23, 3, 24 - seria, originalmente, sobretudo voltada a assuntos negociais, enquanto que, mais tarde, teria se alterado para concessio administratio. GLÜCK, Christian Friedrich. Ausführliche Erläuterung XIV. cit. (nota 11), p. 360 (= §905), afirma que, para a concessio de um peculium, não bastaria a declaração de vontade do pater, mas se exigiria também a entrega. Em sentido oposto, para encerrar o peculium, bastava a manifestação de vontade deste. Cf. Paul. 4 ad Sab., D. 15, 1, 8.

30 BUONAMICI, Francesco. Dell'ordine dei titoli delle Pandette (Dal lib. I al lib. XXV). Pisa: Vannucchi, 1906. v. 1, p. 231-249. Observa-se que não se trata de um título que interrompe o tratamento da matéria, pelo simples fato de começar um novo livro. Existe uma continuidade de pensamento, pelo menos desde D. 14, 5 ("Quod cum eo, qui in aliena potestate est, negotium gestum esse dicetur"), do qual parece ser uma continuação. Mas, na realidade, a lógica começa já antes, desde D. 14, 1, "De exercitoria actione", onde se inicia o tratamento daquelas ações pretórias derivadas de um contrato alheio (salvo uma ou outra interrupção na ordem dos títulos, o raciocínio valeria até D. 15, 4, "Quod iussu"). De fato, a sequência de títulos é interessante nesses dois livros: "De exercitoria actione" (D. 14, 1); "De lege Rhodia de iactu" (D. 14, 2: que merece tratamento à parte, pois, já à primeira vista, não se trata dos livros ad edictum, principalmente o $28^{\circ}$ e $29^{\circ}$, de Ulpiano); "De institoria actione" (D. 14, 3); "De tributoria actione" (D. 14, 4); "Quod cum eo, qui in aliena potestate est, negotium gestum esse dicetur" (D. 14, 5); "De senatus consulto Macedoniano" (D. 14, 6); "De peculio" (D. 15, 1); "Quando de peculio actio annalis est" (D. 15, 2: continuação do título anterior); "De in rem verso" (D. 15, 3); e "Quod iussu" (D. 15, 4).

No mesmo sentido, Soubie, André. Recherches sur les origines des rubriques du Digeste. Tarbes: SaintJoseph, 1960. p. 50-51, diz que D. 14 e 15 são consagrados à representação, articulada pelo sistema das actiones adiecticiae qualitatis. Eles constituiriam uma introdução à matéria, o que seria confirmado por LENEL, Otto. Das Edictum Perpetuum - Ein Versucht zu seiner Wiederherstellung (1883). 3. ed. Amsterdam: Scientia, 1985. p. 263-286 (= § 104), que, em sua reconstrução, inclui, neste parágrafo, o edictum triplex (Ulp. 29 ad ed., D. 15, 1, 1 pr.-1), ou seja, D. 15 consagra um título para cada uma das ações desse edictum: de peculio (D. 15, 1; sendo D. 15, 2, um apêndice do anterior); de in rem verso (D. 15, 3); e quod iussu (D. 15, 4). Um apego, ao autor, à terminologia clássica.

De qualquer forma, Ulp. 29 ad ed., D. 15, 1, 1 pr., explica a colocação de D. 15, 1: "Ordinarium praetor arbitratus est prius eos contractus exponere eorum qui alienae potestati subiecti sunt, qui in solidum tribuunt actionem, sic deinde ad hunc pervenire, ubi de peculio datur actio."

Quanto ao período que essas actiones formaram-se, TALAMANCA, Mario. Istituzioni. cit. (nota 1), p. 8586, diz que esse somente poderia ser determinado genericamente nos dois últimos séculos da República, em razão das grandes alterações sócio-econômicas que teriam ocorrido. Já na segunda metade do século I a.C., o regime estaria plenamente fixado em linhas gerais. Essas actiones cumpriam uma exigência do próprio mercado e das trocas, bem como servem ao próprio interesse do pater. Ademais, a utilização de filii e de servi dependia da disponibilidade de terceiros em aceitar uma relação com aqueles, o que não seria fácil se somente vigorasse a ideia pela qual o pater sempre deveria auferir lucro dos negócios. Neste sentido, as actiones adiecticiae qualitatis permitiam a realização de negócios de forma mais segura com os subiecti.

De forma semelhante, a criação dessas ações para MONIER, Raymond. Manuel élémentaire de droit romain - Les obligations. Paris: Montchrestien, 1948. v. 2, 4. ed., p. 259-260 (= n. 189) visava tão-somente a possibilidade de condenar o pater. Elas estruturariam-se em dois blocos: quod iussu, exercitoria e institoria, onde o pater seria obrigado a reembolsar a totalidade da dívida, quando ele aprovou a prática de certo ato (por exemplo, quando o alieni iuris comanda uma embarcação no comércio marítimo, ou está à frente de um comércio terrestre), ou seja, ele é responsável por todos os atos realizados; e in rem verso, de peculio e tributoria, se a persona que realiza o ato estava submetido a ele e o realiza por meio de um peculium (Gai. 4, 72), quando o alieni iuris tinha um peculium, ou quando o ato aproveitava ao pater, sendo a responsabilidade deste, em todas estas hipóteses, até o montante do peculium, ou de seu enriquecimento, mesmo se a operação não tivesse seu consentimento. 
o dominus, frente ao servus, poderiam ser obrigados ex negotio gestio. ${ }^{31}$ Para tanto a concessio do peculium da parte do pater deve ser notória, ou o autor da actio de peculio deve, ao menos, provar efetivamente esta concessio. ${ }^{32}$

Christian Friedrich Glück ${ }^{33}$ diz que, embora pertencente ao gênero das actiones adiecticiae qualitatis, a actio de peculio distingue-se das demais por não ter, como objeto, todo o valor do débito, "sondern nur soweit das Peculium" [= "mas apenas até o (valor máximo do) peculium"]. ${ }^{34}$ Neste sentido, expressa é a regra de Ulp. 29 ad ed. $15,1,9,2^{35}$. O pressuposto é sempre a existência de um peculium profecticium, deixado pelo pater, à administratio do filius, ou servus.

Sustenta Christian Friedrich Glück ${ }^{36}$ que "nur von diesen Peculium sprechen alle Gesetze dieses Titels" [= "somente deste peculium todas as leis deste título (D. 15, 1) falam"], o que significa que "peculium" é aqui tomado em sua acepção originária, ou seja, "ein solches Vermögen" [= "um determinado patrimônio"] de uma pessoa sob a patria potestas - filius(a) e/ou servus(a) (37 $^{37}$ que estava separado do patrimonium do pater, sendo administrado por um daqueles. ${ }^{38}$

Apenas para dar fundamento à actio de peculio, requer-se que o Besitzer [= "possuidor" $]^{39}$ seja pessoa que se possa obrigar, ou que o poderia fazer se fosse livre.

31 BUONAMICI, Francesco. Dell'ordine. cit. (nota 30), p. 245. Observa-se a alusão do autor a "ex negotio gestio", "proveniente da gestão de um negócio". O que aproxima, ao menos terminologicamente, o instituto da "negotiorum gestio", "gestão de negócios", ao tema.

32 aGUARINO, Antonio. Diritto privato romano. cit. (nota 1), p. $544(=\S 40)$. Embora a condição descrita por Schulting, Anton. Notae ad Digesta seu Pandectas. Lyon: Luchtmans, 1820. t. 3, p. 239: "Quando actio de peculio non competit, peculio non locupletato".

33 GLÜCK, Christian Friedrich. Ausführliche Erläuterung XIV. cit. (nota 11), p. 355 (= § 905).

34 Observa-se que TALAMANCA, Mario. Istituzioni. cit. (nota 1) p. 87-88, considera a actio de peculio a mais difundida e talvez a mais importante, na prática, das actiones adiecticiae qualitatis.

35 "Peculium autem deducto quod domino debetur computandum esse, quia praevenisse dominus et cum servo egisse creditur" [= "E determina-se o (valor) do peculium, uma vez deduzido o que se deve ao dono, porque se considera como se este tivesse se antecipado ao demandar ao seu escravo"]. LEVY, Ernst, e Rabel, Ernest (orgs.). Index Interpolationum quae in Iustiniani Digestis inesse dicuntur - Ad libros digestorum I - XX pertinens. Weimar: Böhlau, 1929. t. 1, p. 247, insere como possível alteração justinianéia "esse - creditur".

36 GLÜCK, Christian Friedrich. Ausführliche Erläuterung XIV. cit. (nota 11), p. 355-356 (= § 905).

37 Gai. 9 ad ed. provinc., D. 15, 1, 27 pr., "Et ancillarum nomine et filiarum familias in peculio actio datur (...)"; e Ulp. 29 ad ed., D. 15, 1, 7, 3, "Pupillum autem tam filium quam servum peculium habere posse Pedius libro quinto decimo scribit, cum in hoc, inquit, totum ex domini constitutione pendeat. (...)". Não existe limitação quanto ao sexo, ou ao status libertatis, para a concessio do peculium. Para GLÜCK, Christian Friedrich. Ausführliche Erläuterung XIV. cit. (nota 11), p. 357 (=§905), este aspecto depende do livre desejo do pater.

38 Essa constatação pode ser alcançada por meio da definição de Ulp. 29 ad ed., D. 15, 1, 5, 3 ("pusilla pecunia sive patrimonium pusillum"), e com a observação, a seguir (Ulp. 29 ad ed., D. 15, 1, 5, 4), de que se trata de um patrimonium à parte administrado por um servus. Cf. nota 22, supra.

A possibilidade, para GLÜCK, Christian Friedrich. Ausführliche Erläuterung XIV cit. (nota 11), p. 356-357 (=§905), de um peculium para um filius, encontra-se em Inst. 2, 9 ("Per quas personas nobis adquiritur"), 1. Sobre o tema, cf. Gai. 4, 69, e Thomas, Yan. Droit domestique et droit politique à Rome - Remarques sur le pécule et les honores des fils de famille. Mélanges de l'École Française de Rome - Antiquité, Roma, v. 94, 1982. p. 533.

39 GLÜCK, Christian Friedrich. Ausführliche Erläuterung XIV. cit. (nota 11), p. 356 (= § 905), trata como 
Assim, sendo o filius impúbere, a actio de peculio volta-se apenas contra o pater, na medida em que o peculium enriqueceu-se/-o com o negócio realizado. ${ }^{40}$

Segundo Paul. 6 brev., D. 14, 1, 6, o negócio realizado entre um escravo domino ignorante, somente é tutelado pela actio de peculio. E, assim, o negócio é plenamente válido e eficaz mesmo sem a vontade do dominus, ou sem, ao menos, a scientia do dominus. ${ }^{41}$

E, já que o peculium profecticium devesse ser concedido pelo pater, a actio de peculio era conferido aos credores do filius e do servus contra aquele, quando não tivesse estes como prepostos em um exercício comercial, e também não tivesse autorizado a realização de um negócio com outrem. Mas isso pressupõe que o pater-dominus tivesse concedido ao filius-servus um peculium, e assim os credores poderiam agir diretamente contra aquele, nos limites do patrimonium peculiar (Gai. 4, 72a: “dumtaxat de peculio")42. Sobre a natureza e origem do peculium profecticium, Max Kaser ${ }^{43}$ acredita que esse deriva do "Dotalrechts" [= "direito ao dote", ou só "dote"]. Em regra, quem

\footnotetext{
"possuidor" aquele que administra o peculium. Também LONGO, Giannetto. Appunti critici in tema di peculio. Studia et Documenta Historiae et Iuris, Roma, v. 1, 1935. passim, fala sempre em "il possessore del peculio".

40 Ulp. 29 ad ed., D. 15, 1, 1, 4: "Si cum impubere filio familias vel servo contractum sit, ita dabitur in dominum vel patrem de peculio, si locupletius eorum peculium factum est.". Na verdade, cf. RODGER, Alan Ferguson. Peculium. cit. (nota 11), p. 1130, o pater-dominus é responsável até o limite do peculium (que constitui, assim, um "patrimônio de risco"), sujeito a deduções no julgamento, ou responsável no limite do que lucrou na transação realizada pelo subiectus (Gai. 4, 72a, actio de peculio et in rem verso). Mas se o subiectus realizou o negócio com conhecimento do pater, este é responsável até o limite do peculium, sem
} direito a reduções (actio tributoria).

Talamanca, Mario. Istituzioni. cit. (nota 1), p. 87-88, explica que a actio de peculio volta-se contra o dominus, por qualquer obrigação assumida pelo filius ou servus, mas nos limites do peculium. Isso era calculado tendo-se em vista os ativos e passivos entre pater-dominus e filius-servus, aqueles que os romanos denominavam, impropriamente, de débitos e créditos frente àquele (a partir do século I d.C. será incluído na categoria das obligationes naturales). Assim, o pater tem uma posição privilegiada frente aos credores, pois os "débitos" que o filius, ou servus, apresenta frente ao pater são substraídos do peculium para determinar o quanto que o pater responde frente aos terceiros, a serem satisfeitos no limite deste ativo. Lembra, ainda, que a insolvência do peculium não equivale à sua inexistêcia, uma vez que, por exemplo, na hipótese em que o pater revoga o peculium ou liberta um escravo, a actio de peculio poderia ser utilizada, pelos credores, dentro de um ano contado da extinção do peculium, contra o pater ou o próprio escravo libertado (inovação que aparece em 422 d.C., com o C. Th. 2, 32, 1 = Honor. et Theod., C. 4, 26, 13, 4).

SOLAZZI, Siro. Sul peculium nell'actio de in rem verso. Archivio Giuridico "Filippo Serafini", Modena, v. 152, 1957. p. 3-18, defende que a responsabilidade de in rem verso não existe nos negócios jurídicos de um filius, ou de um servus, sem a existência de um peculium.

41 PESARESI, Roberto. Ricerche cit. (nota 19), p. 17.

42 GUARINO, Antonio. Diritto privato romano. cit. (nota 1), p. $412-413$ (= § 26).

43 KASER, Max. Das Römische Privatrecht - Das altrömische, das vorklassische und klassische Recht. München: Beck, 1971. v. 1, 2. ed., p. $344(=\S 83)$.

TALAMANCA, Mario. Istituzioni. cit. (nota 1), p. 87, propriamente sobre o peculium, acredita que o instituto surgiu, em um primeiro momento, apenas para os filii, já que esses estariam, até a morte do pater, sob seu domínio. Concedia-se, desta forma, alguma liberdade a eles.

Já HEINRICHS, Johannes. Peculium. cit. (nota 4) p. 462, acena que a ambivalência do peculium estar juridicamente no patrimonium do pater, mas "de fato" com o filius, já se encontra nas XII Tab. 7, 12. 
constitui o dote seria de preferência o pater da esposa, salvo se esta fosse sui iuris (quando ela mesma constitui o dote) ou quando um terceiro, o que também não seria raro, o fizesse.

Chamar-se-ia "dos profecticia" - cuja definição encontra-se em UE 6, $3{ }^{44}$ - quando o pater da esposa, e, mais tarde, quando ela, em referência aos bens de seus antepassados que não estão em seu poder, constitui o dote. ${ }^{45}$

\section{Administratio do Peculium Profecticium e Familia Romana}

Christian Friedrich Glück ${ }^{46}$ afirma que, por ser entregue pelo pater, já que sai de seu patrimônio por um ato essencialmente voluntário e não imposto pela lei, o peculium profecticium seria de sua propriedade. Assim, também pertence ao pater o uso e lucro de qualquer forma.

Desta forma, a princípio, o filius teria "eine prekaire Administration" [= "uma administração precária"], ${ }^{47}$ embora possa adquirir a propriedade deste. ${ }^{48}$

Essa livre administração consentia ao filius uma série de atos, como vender as coisas do próprio peculium, ${ }^{49}$ poder realizar uma novatio, ${ }^{50}$ embora não pudesse doar nada do peculium, nem dissipá-lo. ${ }^{51}$

Hipótese diversa ocorre quando, ao invés de constituir um peculium, o pater realiza uma doação ao filius, e tudo o que este adquire do patrimonium daquele, por força de um preceito legal, torna-se seu, como, por exemplo, os presentes nupciais que o pater dá à filia. ${ }^{52}$

44 "Dos aut profecticia dicitur, id est quam pater mulieris dedit, aut aduenticia, id est ea quae a quouis alio data est" [= "Ou o dote chama-se profecticia, isto é, aquele que o pater da mulher deu, ou adventicia, aquele que por qualquer outro é entregue"]. KASER, Max. Das Römische Privatrecht I. cit. (nota 43), p. 334 (= § 80) e Jav. 1 epist., D. 42, 5, 28. As definições de dos adventicia, constituido por alguém diverso do pater, e dos recepticia, para o qual a restituição a quem o constitui fica ajustada, derivam das escolas jurídicas do período clássico. Cf. UE 6, 3 e 5.

45 Sobre a restituição do dos profecticia, cf. também UE 6, 4 e 6.

46 GLÜCK, Christian Friedrich. Ausführliche Erläuterung XIV. cit. (nota 11), p. 365-366 (= § 907). Ele acrescenta "und nicht in der Absicht gegeben wurde, daß es ein militairisches Peculium weden solle", ou seja, não é entregue com a intenção que se torne um peculium castrense.

47 Inst. 2, 9, 1; e Ulp. 44 ad Sab., D. 39, 5, 7 pr. ["Fiiusfamilias donare non potest, neque si liberam peculii administrationem habeat: non enim ad hoc ei conceditur libera peculii administratio, ut perdat"]. No mesmo sentido, MANDRY, Gustav. Das gemeine Familiengüterrecht. cit. (nota 11), p. 86 (= § 61): "Der Peculieninhaber ist immer und nothwendig eine gewaltunterworfene Person, das Peculium sein faktisches, aber auch nur sein faktisches Vermögen".

48 GLÜCK, Christian Friedrich. Ausführliche Erläuterung II. cit. (nota 21), p. 254 (= § 136): “Wenn serner der Vater den Sohn emancipirt, ohne dieses Peculium zurückzuforden, so wird angenommen, der Vater habe es ihm stillschweigend geschenkt. Diese Grundsätze des Röm. Rechts sinden auch noch heutiges Tages statt."

49 Diocl. et Max., C. 4, 26, 10 [=294 d.C.].

50 Gai. 3 de verb. obligat., D. 46, 2, 34 pr.

$51 \quad$ Ulp. 29 ad ed., 14, 6, 3, 2; e Ulp. 44 ad Sab., D. 39, 5, 7 pr.

52 Ulp. 11 ad ed., D. 4, 4, 3, 5; Paul. 2 quaest., D. 10, 2, 36; Ulp. 25 ad ed., D. 11, 7, 16; e Paul. 16 quaest., D. 21, 2, 71. GLÜCK, Christian Friedrich. Ausführliche Erläuterung XIV. cit. (nota 29), p. 366-367 (= § 907), afirma que se admite que o pater doasse ao filius e sobre estes bens não pudesse ser demandado. Não se 
Essa problemática envolve seguramente o que se deve entender por "libera administratio peculii", ${ }^{53}$ o que necessariamente não pode considerar apenas opiniões dogmáticas, mas encontrar um subsídio seguro nas fontes. ${ }^{54}$

Importante texto, no tema, é Ulp. 29 ad ed., D. 15, 1, 7, 1: “(...) alia causa est peculii liberae administrationis: nam haec specialiter concedenda est." [= "(...) diferente é a livre administração do pecúlio, pois esta deve ser concedida especialmente"]. Neste texto, seguramente, sustenta-se que, no período justinianeu, concessio peculii e concessio liberae administrationis seriam distintas. Aliás, não apenas é o único texto em que a expressão se encontra, mas onde se exige um ato distinto da concessio peculii para existir a administratio peculii. ${ }^{55}$

E, nesta direção, poderia ser considerado interpolado Paul. 62 ad ed., D. 15, 1, 46: "Qui peculii administrationem concedit, videtur permittere generaliter, quod et specialiter permissurus est" [= "Quem concede a administração do pecúlio, parece

poderia, assim, confundir doação com peculium profecticium, já que este ocorreria quando o pater concede ao filius a pura e simples administração, reservando-se expressamente a propriedade.

Cf., também, sobre a distinção e validade desta doação, __ . Notas a Glück C. F. Ausführliche Erläuterung der Pandecten nach Hellfeld: ein Commentar, trad. em ital., Commentario alle Pandette tradotto ed arricchito di copiose note e confronti col Codice Civile del Regno d'Italia. Milano: Libraria, 1907. v. 14 e 15, p. $162-$ 166.

53 Cf. LONGO, Giannetto. Il concetto classico e il concetto giustinianeo di « administratio peculii ». Archivio Giuridico "Filippo Serafini”, Modena, v. 100, 1928. p. 184. A expressão "administratio peculii" refere-se a um "insieme degli atti di disposizione giuridica che il possessore del peculio può compiere su di esso". Sua relevância corresponde exatamente à função econômico-social dos peculia no contexto romano em questão, sendo tão ampla como o conceito clássico de "administratio", que não encontra, em um paralelo com a atualidade, uma disponibilidade jurídica tão grande.

54 LONGO, Giannetto. Libera administratio peculii - I limiti e lo spirito di una innovazione giustinianea. Bullettino dell'Istituto di Diritto Romano, Roma, v. 38, 1930. p. 30-32. Existem dois problemas centrais: primeiro é a menção expressa, ou não, nas fontes de uma "administratio"; e o segundo a diferença entre esta e a "concessio peculii". O primeiro é que não existe necessidade que a fonte diga expressamente a existência de uma "administratio peculii", ou de "concessio (liberae) administrationis", para que o subiectus possa realizar um determinado negócio [e existiriam, cf. LONGO, Giannetto. Il concetto classico cit. (nota 53), p. 201, textos genuínos que não mencionam "administratio peculii": Paul. 3 ad ed., D. 2, 14, 27 pr.; Alf. Var. 1 dig. a Paul. epit., D. 41, 3, 34; Jul, 4 ex Minc., D. 46, 1, 19; Proc. 7 epist., D. 46, 3, 84; e Cel. 1 dig., D. 46, $2,25]$. O segundo é que a "concessio peculii" e a "administratio peculii" são dois atos de vontade distintos do pater apenas com Justiniano, ou seja, as escolas dos juristas clássicos já reconhecem, na constituição de um peculium ao filius, ou ao servus, que estes possam realizar determinados negócios jurídicos. Assim, na linguagem clássica, "habere peculium" somente pode significar o fato de receber um peculium e poder fazer seus bens circularem pelo comércio jurídico. Em outras palavras, a "administratio peculii" seria inerente ao próprio peculium.

Desta forma, "administratio" foi um conceito que sofre um processo de restrição por parte dos juristas justinianeus, exigindo-se, assim, a necessidade, para o administrador, de um mandato especial, ou da concessão de uma expressa libera administratio, o que também conduziu a uma separação entre concessio peculii e concessio liberae administrationis. Mas, também LONGO, Giannetto. Appunti critici. cit. (nota 39), p. 400, sustenta que é vital compreender a concessio peculii para determinar a evolução histórica do instituto do peculium.

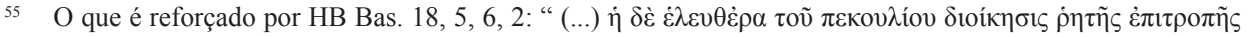

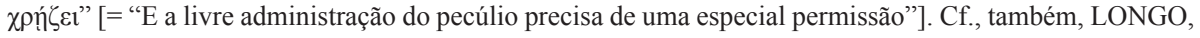
Giannetto. Appunti critici cit. (nota 39), p. 33-34. 
permitir, em regra, o que haveria de permitir especialmente"], em decorrência do próprio Ulp. 29 ad ed., D. 15, 1, 7, $1^{56}$.

Em outros textos, também se percebe a separação entre os dois conceitos: ${ }^{57}$ Gai. 1 ad ed.provinc., D. 2, 14, 28, 2; Marc. ad form. hypoth., D. 20, 6, 8, 5; Pomp. 15 ad Sab., D. 23, 3, 24; Paul. 68 ad ed., D. 41, 2, 14, 1; e Proc. 7 epist., D. 46, 3, 84.

Porém, em uma outra série de textos, aparece não o conceito justinianeu, mas sim o clássico, pelo qual concessio peculii e administratio peculii estão inseridas em um mesmo ato: Ulp. 26 ad ed., D. 12, 1, 11, 2; Paul. 18 ad ed., D. 12, 2, 20; Ulp. 37 ad ed., D. 47, 2, 52, 26; e Gai. 3 de verb. oblig., D. 46, 2, 34 pr. $^{58}$

Essa organização da matéria operada por Giannetto Longo, opõe-se nitidamente à constatação oferecida por G. Mandry, ${ }^{59}$ segundo a qual sempre teria existido a necessidade de uma concessio especial por um ato do pater para que o filius pudesse realizar negócios com as res peculiares.

Segundo Gustav Mandry ${ }^{60}$ e, depois, reportada, em parte, por Giannetto Longo, ${ }^{61}$ os atos que poderiam ser realizados pelo filius na administratio peculii seriam: pactum de non petendo, ${ }^{62}$ transactio $;{ }^{63}$ pactum ne res pignori sit $;{ }^{64}$ novatio $;{ }^{65}$ constituição

56 LONGO, Giannetto. Libera administration. cit. (nota 54), p. 35-36. Um outro texto onde novamente um complexo de faculdades a ser concedidas trata-se de um ato diverso daquele com o qual se concede o

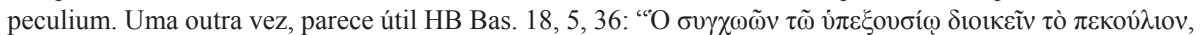

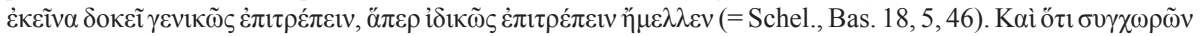

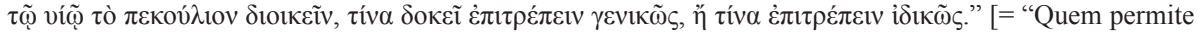
a outrem administrar um pecúlio, que está sob seu poder, parece, em regra, permitir por ela o que haveria de ser especialmente. O mesmo com aquele que permite ao filho administrar um pecúlio, em regra, parece permitir especialmente"].

A necessidade da concessio da administratio peculii também é atestada por PESARESI, Roberto. Ricerche. cit. (nota 19), p. 18-37.

57 LONGO, Giannetto. Libera administratio cit. (nota 54), p. 35-37.

58 LONGO, Giannetto. Libera administratio cit. (nota 54), p. 37-48.

59 MANDRY, Gustav. Das gemeine Familiengüterrecht cit. (nota 11), p. 86-88 (= § 61).

60 MANDRY, Gustav. Das gemeine Familiengüterrecht cit. (nota 11), p. 86-88 (= $\S 61$ ). Para MARRONE, Matteo. Istituzioni. cit. (nota 13), p. 248 (= §98), a situação patrimonial do filius tende a melhorar ao final da República, onde se admite, por exemplo, que ele possa realizar, com responsabilidade do pater, alguns atos formais de disposição, como a novatio e a manumissio vindicta, e, em seguida, a ele seria permitido assumir debita autônomos, pelos quais os credores o podem obrigar em juízo a sofrer uma condenação, salvo na hipótese de execução forçada, pela qual se enfraqueceria a patria potestas.

61 LONGO, Giannetto. Appunti critici. cit. (nota 39), p. 185-186

62 Gai. 1 ad ed.provinc., D. 2, 14, 28, 2; Ulp. 4 ad ed., D. 2, 14, 29; e Ulp. 37 ad ed., D. 47, 2, $52,26$.

63 Ulp. 37 ad ed., D. 47, 2, 52, 26.

64 Marc. ad form. hypoth., D. 20, 6, 8, 5.

65 Gai. 5 ad ed. prov., D. 12, 2, 21; Paul. 17 ad Plaut., D. 15, 1, 48, 1; e Gai. 3 de verb. oblig., D. 46, 2, 34 pr. 
dotal de res peculiares ${ }^{66}$ mutuum $;{ }^{67}$ emptio-venditio $;{ }^{68}$ aceitação de pagamento; ${ }^{69}$ pagamento de débitos com o peculium; ${ }^{70}$ e oferecer, bem como aceitar, juramento. ${ }^{71}$

Desta forma, resta fora desta lista de atos possíveis de serem realizados com a administratio peculii todo aquele de disposição das res peculiares que não tivesse uma contraprestação. ${ }^{72}$ Por isso, não é estranho que as doações fossem proibidas, especialmente as mortis causa (Ulp. 44 ad ed., D. 39, 5, 7 pr.). ${ }^{73}$

As teorias para explicar este fenômeno foram várias, dentre as quais, Friedrich Ludwig von Keller ${ }^{74}$ - limita a necessidade da concessio administrationis à alienação das res peculiares, mas ainda os confins daquela poderiam ser elásticos e, de qualquer forma, faltando a concessio poderia-se recorrer à vontade expressa ou tácita do pater para cada alienação - Berhard Windscheid ${ }^{75}$ - defende que aparecendo o adjetivo "libera" com "administratio", inclui-se expressamente a faculdade de alienar, embora "in anderen Stellen wird denn auch von administratio schlechthin, in noch anderen von administratio und libera administratio abwechselnd gesprochen" ["em outras passagens será dito, pois, também da administratio por excelência, em outras, ainda, de administratio e libera administratio de forma alternada" $]^{76}$ - e Alois Brinz ${ }^{77}$ - o simples peculium traria em si a faculdade de realizar certos atos de administratio, sendo que somente seria exigido a expressa e especial concessio administrationis para atos que não são apenas um dever,

66 Pomp. 15 ad Sab., D. 23, 3, 24.

67 Ulp. 26 ad ed., D. 12, 1, 11, 2; Ulp. 29 ad ed., D. 14, 6, 3, 2; e Gord., C. 8, 42, 3 [= 238 d.C.]

68 Ulp. 27 ad ed., 6, 1, 41, 1; Paul. 29 ad ed., D. 13, 7, 18, 4; Marc. ad form. hypoth., D. 13, 7, 19; Paul. 69 ad ed., D. 41, 2, 14 pr.; Marc. 18 dig., D. 42, 8, 12; Ven. 5 insterd., D. 44, 3, 15, 3; e Diocl. et Max., C. 4, 26, 10 [= 294 d.C. $]$.

69 Paul. 18 ad ed., D. 12, 2, 20; Gai. 5 ad ed. provinc., D. 12, 2, 21; Pomp. 15 ad Sab., D. 23, 3, 24; Cel. 1 dig., D. 46, 2, 25; e Gord., C. 8, 42, 3 [=238 d.C.].

70 Paul. 10 ad Sab., D. 12, 6, 13 pr.; e Proc. 7 epist., D. 46, 3, 84.

71 Paul. 18 ad ed., D. 12, 2, 20.

72 LONGO, Giannetto. Il concetto classic. cit. (nota 54), p. 186. Assim, o subiectus poderia penhorar uma coisa do peculium para si, mas não para outrem; poderia fazer um pactum de non petendo, se não tivesse o animus donandi; só poderia renunciar ao penhor, se recebesse um preço pro pactione; poderia fazer novatio, se isso melhorasse sua situação; e, para incremento do peculium, poderia delegar a um credor. Estaria na raiz desse pensamento o texto de Ulp. 29 ad ed., D. 14, 6, 3, 2 [“(...) non enim perdere ei peculium pater concedit, cum peculii administrationem permittit (...)"] e de Ulp. 44 ad ed., D. 39, 5, 7 pr. [“(...) non enim ad hoc ei conceditur libera peculii administratio, ut perdat'].

73 Embora reticente quanto à necessidade da libera administratio peculii acompanhar ou não sua concessio, TALAMANCA, Mario. Istituzioni. cit. (nota 1), p. 87, diz que, mesmo com aquela, os atos de disposição, a título gratuito, são proibidos.

74 KELLER, Friedrich Ludwig von. Pandekten. Leipzig: Tauchnitz, 1861. p. $770(=\S 415)$.

75 WINDSCHEID, Berhard. Lehrbuch des Pandektenrechts. Frankfurt: Loening, 1901. v. 3, 8. ed., p. 80 (= $\S$ 518).

76 Exatamente, Gai. 1 ad ed.provinc., D. 2, 14, 28, 2; Ulp. 29 ad ed., D. 14, 6, 3, 2; e Paul. 16 ad Plaut., D. 15, 1,48 .

77 BRINZ, Alois. Lehrbuch der Pandekten. Erlangen: Deichert, 1886. v. 3, 2. ed., p. $625-629$ (= § 461$)$. LONGO, Giannetto. Il concetto classic. cit. (nota 54), p. 188, afirma que seria uma posição sem fundamento nas fontes. 
mas uma faculdade de quem os realiza, isto é, que se referissem mais ao juízo pessoal do agente do que ao objeto em si do peculium.

Gabriel Micolier ${ }^{78}$ desafia a tese de Giannetto Longo, afirmando que se fosse distinto o sentido, nas escolas clássicas e no período justinianeu, de "admininistratio peculii", na verdade, não se compreende mais o motivo dos compiladores usarem como sinônimo "administratio peculii" e "libera administratio peculii". Em sentido contrário, Emilio Albertario, ${ }^{79}$ agora no caminho de Giannetto Longo, defende, que a administratio peculii, no período justinienau, já apresentava um sentido moderno e que não mais importa a concessio peculii.

Seja como for, uma perspectiva pode ser tomada neste estudo: a natureza do peculium está intrinsecamente relacionada com o crescimento econômico-social de Roma, decorrente da necessidade de existirem serviços e atividades das pessoas sobre a potestas, capazes de realizar uma atividade negocial à parte, mas no interesse da familia $\mathrm{e}$ do pater (uma familia em expansão). ${ }^{80}$

Desta forma, enquanto a propriedade ficava com o pater, cria-se o mecanismo em que o conjunto de bens ficava separado dos demais, sendo que, de qualquer forma, o filius, ou o servus, teria a livre-administração, podendo deles dispor, embora não realizar certos atos. ${ }^{81}$

Neste sentido, Roberto Pesaresi ${ }^{82}$ afirma que a gênese da organização empreenditorial romana pode ser datada do século II a.C., quando ocorre uma época de grande expansão imperialísitca e de intenso desenvolvimento comercial, que gera o aparecimento no edictum da actio institoria, da actio exercitoria, da actio de peculio et de in rem verso, da actio tributoria e da actio quod iussu. ${ }^{83}$

78 MICOLIER, Gabriel. Pécule et capacité patrimoniale. cit. (nota 12), p. 490-491.

79 ALBERTARIO, Emilio. Sulla "libera administratio peculii". Rendiconti del Reale Istituto Lombardo di Scienze e Lettere, Milano, v. 61, 1929. p. 848. No Corpus Iuris Civilis, o sentido de administratio deveria mudar para estar de acordo com as faculdades dos outros administradores, cf. LONGO, Giannetto. Appunti critici. cit. (nota 39), p. 422.

80 BERGER, Adolf. Encyclopedic Dictionary. cit. (nota 4), p. 624. No mesmo sentido, BURDESE, Alberto. Considerazioni in tema di peculio c.d. profettizio. In: Studi in Onore di Cesare Sanfilippo. Milano: Giuffrè, 1982. p. 95-111, para o qual, a concepção arcaica seria do reconhecimento ao subiectus, principalmente, do servus, sem posteriores autorizações por parte do dominus-pater, de efetuar negócios jurídicos com as res peculiares, com eficácia também frente a este. O que decorreria da própria definição de peculium de Tuberão, reportada em Ulp. 29 ad ed., D. 15, 1, 5, 4.

81 BERGER, Adolf. Encyclopedic Dictionary. cit. (nota 4), p. 624.

82 PESARESI, Roberto. Ricerche. cit. (nota 19), p. 15-17. O que é confirmado por TALAMANCA, Mario. Istituzioni. cit. (nota 1), p. 85-86, e nota 30, supra. Cf., também, CAPOGROSSI COLOGNESI, Luigi. Patria potestà (diritto romano). Enciclopedia del Diritto, Milano, v. 32, 1982, p. 246, para quem o peculium, no período republicano, seria entregue ao filius por motivos de "esigenze pratiche (opportunità di una amministrazione decentrata) o per ragioni di decoro e di carattere sociale".

83 Atualmente, não se pode esquecer também de SERRAO, Feliciano. Impresa e responsabilità a Roma nell'età commerciale - Forme giuridiche di un'economia-mondo. Pisa: Pacini, 1995. p. 6-9, que trata da "impresa collettiva romana", ou seja, um discurso fundado principalmente na praepositio; na responsabilidade solidária de vários empreendedores (Ulp. 28 ad ed., D. 14, 3, 13, 2), pelas actiones institoria, exercitoria e 
E, neste contexto, o peculium, com o aparecimento da actio de peculio, ganha sua fisionomia própria como patrimônio separado daquele do pater e destinado ao exercício de uma empresa commercial. ${ }^{84}$ Constrói-se o peculium como um "patrimônio de risco", ${ }^{85}$ que serve para a atividade empresarial, bem como cria-se uma limitação da responsabilidade do pater, que responde nos limites do peculium e da versio pelas dívidas, salvo se tiver autorizado o negócio, ou dele tiver conhecimento. ${ }^{86}$

Embora juridicamente este peculium fosse do pater, que o poderia revogar a qualquer momento, socialmente constituía um complexo de bens do filius que comportava, dentro do limite do próprio peculium, a validade dos atos de disposição e das obrigações assumidas.

É um regime que nitidamente reflete as exigências da celeridade e certeza do mundo comercial e dos negócios. Assim, a actio de peculio apresenta uma natureza subsidiária e inderrogável, em garantia de terceiros, uma vez que tem aplicação quando a

de peculio; e na existência de algumas empresas coletivas, como banqueiros e armadores, que tem, como ato constitutivo, o contrato de sociedade. Isso demonstraria que a relevância externa da empresa coletiva reflete-se no próprio contrato em questão. Os romanos teriam feito um "organismo complesso", no qual uma divisão de seus elementos os destruiria (sendo uma de suas formas de configuração a concessão e copropriedade do peculium como patrimônio empreenditorial). E, assim, "bisognerebbe dire che il problema della rilevanza esterna del rapporto di società è assorbito dal problema, più ampio e più concreto, della rilevanza esterna dell'impresa collettiva".

Cf., também, COSTA, Emilio. Le azioni exercitoria e institoria nel diritto romano. Parma: Battei, 1891. p. 19, que parte do“organamento economico della familia" para desenvolver as actiones adiecticiae qualitatis, frutos do desenvolvimento comercial mais rápido e frequente, que se intensificou no século II a.C. Ademais, KASER, Max. Das Römische Privatrecht - Der altertumswissenschaft. München: Beck, 1975. v. 2, 2. ed., p. $219(=\S 230)$, sustenta que a actio de peculio não foi transmitida da pars Occidentis.

84 PESARESI, Roberto. Ricerche. cit. (nota 19), p. 15-17. O intervento edital cumpre, assim, um papel fundamental, uma vez que o pater-dominus responde nos limites do peculium ou da actio in rem verso, pelas dívidas do servus, e mesmo por negócios realizados por este, sem intervento do dominus. Mas a presença da actio de peculio permite também a distinção entre peculium e res domini, sendo possível sua oposição frente a terceiros. A tendência, assim, era conceder a actio de peculio, mesmo quando os filii ou servi não eram prepostos em uma atividade e não tivessem um peculium, o que permite à jurisprudência, paulatinamente, construir e admitir uma constiuição tácita do peculium, por facta concludentia, passando a ser irrelevante um ato do pater, mas apenas necessária sua tolerância. Cf. Marc. 5 reg., D. 15, 1, 40, 1, e Pomp. 4 ad Q. Muc., D. 15, 1, 49 pr.

Sobre o incremento da atividade empreenditorial, isso se vê pela maior concessão da actio de peculio, Paul. 30 ad ed., D. 14, 3, 17, 4; Gai. 9 ad ed. provinc., D. 15, 1, 29, 1; e Paul. 4 ad Plaut., D. 15, 1, 47 pr.

Tambem se ressalta que Roma passava por uma transformação econômico-social mais ampla, ao menos a partir do século IV a.C., como ressalta CAPOGROSSI COLOGNESI, Luigi. Max Weber e le economie del mondo antico. Roma: Laterza, 2000. p. 15, quando se passa a buscar novas terras agrículas aos cidadãos romanos e uma nova direção política da parte de pequenos proprietários plebeus que controlaram a expansão territorial.

85 DI PORTO, Andrea. Impresa collettiva e schiavo 'manager' in Roma antica (II sec. a.C. - II sec. d.C.). Milano: Giuffrè, 1984. p. 355-356 (= § 3), mostra, com base em Gai. 9 ad ed.provinc., D. 15, 1, 27, 8, que o universum, ou solidum, peculium, é determinado após as deduções que cada dominus poderia fazer de seus próprios créditos. Ou seja, todo o peculium, que o dominus responde, é a soma das quotas - com o valor no momento da condenação - resultante após as deduções que cabe a cada um. Disto decorre que o dominus responsável abate não somente os próprios créditos, mas também aqueles dos outros condôminos.

86 PESARESI, Roberto. Ricerche. cit. (nota 19), p. 16-17. 
negotiatio é concluída por um subiectus. Permanece, por conta e ato voluntário do paterdominus, a possibilidade dos credores de ter o remédio mais efetivo da actio quod iussu, ou ainda que se agiu sciente domino, ou contra a posição de credor privilegiado, para fazer valer a posição da par condictio creditorum, recorrendo à vocatio in tributum ou à actio tributoria. ${ }^{87}$

Por fim, nesta análise, deveria-se ainda contrapor duas espécies de peculia, já bem delineados no período justinianeu: o peculium adventicium, ${ }^{88}$ ou seja, tudo que o filius adquire pelo seu trabalho e por uma liberalidade - doação e legado - de terceiros (bens que seriam de propriedade do filius, mas com usufructus do pater); e o profecticium que constitui a regra geral, ou seja, o peculium dado pelo pater ao filius. ${ }^{89}$

Curioso é uma denominação que surge como "peculium paganum", nome conferido por Justiniano para o "ordinary peculium"[= "peculium comum"], em contraposição ao peculium castrense e quasi castrense. ${ }^{90}$

Sobre a tradição jurídica sucessiva, Manlio Bellomo ${ }^{91}$ sustenta que a realidade patrimonial da familia, também no período medieval (debate, este, que

87 PESARESI, Roberto. Ricerche. cit. (nota 19), p. 17.

88 Além do peculium quasi castrense, Constantino traria um outro elemento à "sujeição-independência" patrimonial dos filii, isto é, que os bens deixados mortis causa pela mãe àqueles, com ou sem testamento, seriam adquiridos pelo pater apenas a título formal, mas ficavam a eles reservados. Sucessivamente, afirmaria-se que sobre os bona materna [= "bens maternos"] ao pater tivesse um tipo de usufructus e que la nuda proprietas coubesse ao filius in potestate. Regime estendido aos bens deixados pela mãe ao filius por um legado, e àqueles que este herdasse dos ascendentes maternos (bona materni generis). Elementos que, cf. GUARINO, Antonio. Diritto privato romano. cit. (nota 1), p. 545-546 (= $\S 40)$, vão compor o conceito de "peculium adventicium", "adventicium" ou "bona adventicia" - Just., C. 6, 61, 6 (= 529 d.C.). FUMAGALLI, Marcella Balestri. Persone e famiglia cit. (nota 1), p. 454, vai além, ao afirmar que neste conceito de "peculium adventicium" entram os bens recebidos a qualquer título de pessoas diversas do pater, mesmo que posteriormente. Com Justiniano, seria reconhecido um "direito de propriedade" do filius. É assim que surgeria a ampla disciplina do peculium adventicium, contraposta ao arcaico e restrito peculium profecticium, de terminologia não-romana, que Justiniano mantém em vigor. Sobre o peculium adventicium, cf. atualmente Wesener, Gunter. Peculia - Bona adventicia - Freies und unfreies Kindesgut. In: Ivris Vincvla - Studi in onore di Mario Talamanca. Napoli: Jovene, 2001. v. 8, p. 393-419.

$89 \quad$ BERGER, Adolf. Encyclopedic Dictionary. cit. (nota 4), p. 624.

90 BERGER, Adolf. Encyclopedic Dictionary. cit. (nota 4), p. 624. Sobre o peculium paganum, cf. Just., C. 3, 28, 37, 1 (= 531 d.C.) [“In castrensibus etenim peculiis introducta est et alia subdivisio et peculii triplex invenitur causa. vel enim paganum est peculium vel castrense vel quod medietatem inter utrumque obtinet, quod quasi castrense nuncupatur" (= De fato, com os pecúlios militares foi introduzida uma outra subdivisão e se encontram três espécies de pecúlio. Então ou o pecúlio é ordinário, ou militar, ou tal que se encontra entre ambos, o que se chama como se fosse militar)]. FITTING, Hermann. Das Castrense Peculium. cit. (nota 1), p. 390-391 (= §54).

91 BELlOMO, Manlio. Famiglia (diritto intermedio). Enciclopedia del Diritto, Milano, v. 16, 1967. p. 753755. Logo, no decorrer de sua vida, como no Direito Romano, um filius poderia testemunhar a formação de quatro peculia diversos - castrense, quasi castrense, profecticium e adventicium - cada qual regulado por suas regras, mesmo que estas, às vezes, se confundam.

VACCARI, Pietro. Famiglia (diritto intermedio). Novissimo Digesto Italiano, Torino, v. 7, 1981. p. 4648, afirma que a disciplina romana, segundo a qual as aquisições do filius passavam para a propriedade paterna, quando vinham do peculium, e eram, quando vinham ex alia causa, de propriedade do filius, mas com usufructus do pater, continuou durante muito tempo. A escola dos glosadores teria se direcionado para 
permaneceria mesmo após o Renascimento), ${ }^{92}$ seria composta do patrimonium, que cabia ao pater, bem como de vários peculia, sobre os quais o filius tinha direito de natureza e amplitude diversa.

Quanto ao peculium profecticium, este ainda apresentava o problema da independência do patrimonium, do pater, frente aos demais peculia, pois, em seu caso, a patria potestas o atingia diretamente. Em sentido oposto, o filius teria o peculium adventicium, decorrente de várias origens, mas cuja relação jurídica base era a "nupropriedade" do filius e o "usufruto legal" do pater. ${ }^{93}$

Desta forma, distinguia-se o direito do pater sobre os diversos tipos de pecunia: uma potestas máxima sobre o profecticium, quase nula nos castrense e quasi castrense - com propriedade do filius e usufructus do pater - ou no adventicium - com propriedade plena do filius. ${ }^{94}$

uma outra direção, na qual, mesmo sendo constituídos pelo pater, os bens que o filius adquiria no exercício comercial, seriam dele. E a doutrina avançaria ainda mais no período moderno, quando, na dúvida dos lucros ex profecticia an ex adventicia causa, concederá ao filius a propriedade quando negocia em nome próprio e por próprio perigo. As presunções começam a valer para o filius e não mais para o pater.

No direito longobardo, existia uma regra, transcrita em Roth. 167, segundo a qual até quando o filho ficasse em casa o que ele adquiria iria a favor do pai, mesmo que o realizasse foras in exercitum: "De fratres, qui in casam communem remanserent - Si frates post mortem patris in casa commune remanserint, et unus ex ipsis in obsequium regis aut iudicis aliquas res adquesiverit, habeat sibi in antea absque portionem fratrum; et qui foras in exercitum aliquit adquisiverit, commune sit fratribus quod in casa commune dimiserit (...)". Cf. SCHWARZENBERG, Claudio. Patria potestà (diritto intermedio). Enciclopedia del Diritto, Milano, v. 32, 1982. p. 251.

92 Sobre o aspecto patrimonial dos peculia no Direito Civil moderno, cf. bibliografia e síntese em CICCARELLO, Sebastiano. Patria potestà (diritto privato). Enciclopedia del Diritto, Milano, v. 32, 1982. p. 255-263.

93 BELLOMO, Manlio. Famiglia. cit. (nota 91), p. 753-755. Em algumas hipóteses reconhecia-se até o pleno dominium do filius no peculium adventicium.

94 Observa-se a existência do peculium adventicium extraordinarium, ou irregulare, quando o pater não tem nem o usufructus dos bens do filius, o que ocorreria em algumas hipóteses restritas. Cf. GLÜCK, Christian Friedrich. Ausführliche Erläuterung XIV. cit. (nota 29), p. 384-389 (= § 910).

A relação entre patria potestas e peculia também aparece em Siete Partidas 4, 17, 5: "Qué fuerza ha este poder que ha el padre sobre sus fijos en razon de los bienes que ellos ganan - En tres guisas se departen las ganancias que facen los fijos mientre estan en poder de sus padres: la primera es de aquello que ganan los fijos con los bienes de los padres, et á tal ganancia como esta llaman en latin profectitium peculium; ca quanto quier que ganen desta manera ó por razon de sus padres, todo es de los padres que los tienen en su poder. La segunda es lo quel fijo de alguno ganase por obra de sus manos por algunt menester, ó por otra sabidoria que hobiese ó de otra guisa, ó por donacion quel diese alguno mientre viviese, ó en su testamento, ó por herencia de su madre ó de alguno de los otros parientes della ó de otra manera, ó si fallase tesoro ó alguna otra cosa por aventura; ca de las ganancias que feciese el fijo por qualquier destas maneras que non saliesen de los bienes de su padre nin de su abuelo, debe seer la propiedat del fijo que las ganó, et el usofruto del padre en su vida por razon del poderio que ha sobre el fijo: et á esta ganancia llaman en latin adventitia, porque viene de fuera et non por los bienes del padre. Pero el padre decimos que debe defender, et guardar et aliñar estos bienes adventicios de su fijo en toda su vida, tambien en juicio como fuera de juicio. La tercera manera de bienes et de la ganancia dellos es la que dicen en latin castrense vel quasi castrense peculium, asi como se muestra adelante". De fato, sobre este último peculium, Siete Partidas 4, 17, 6, diz: “(...) Et aun porque tales ganancias como estas facen los homes con grant trabajo et con grant peligro, et porque las facen en tan nobles logares, por ende son quitamiente de los que las ganaren, et son mas franqueadas que otras ganancias; 
Portanto, o que se encontra como pano de fundo do instituto do peculium é a estrutura da familia romana e os diálogos possíveis com a patria potestas..$^{95}$

Curiosamente, Pietro Bonfante ${ }^{96}$ fala em "condominio familiare", já que, como parte do Populus Romanus Quirites, a familia gozava de uma autonomia no sentido que o patrimonium era de sua propriedade e destinada ao seu bem comum. E o poder desta está nas mãos do pater, que deve gerir o patrimonium no interesse de todos.

Ensina que o filius torna-se um "strumento poderoso per il paterfamilias", posição ao mesmo tempo de incapacidade consigo, mas capaz para outrem. O que dialoga com a própria natureza política da familia: a unidade patrimonial da familia significa sua unidade jurídica ao externo, ou seja, frente ao ius civile. ${ }^{97}$

Para Pietro Bonfante, o peculium, principalmente, o profecticium, não enfraquece a unidade patrimonial da familia. ${ }^{98}$ Obviamente, o quadro dos peculia, no período justinianeu, demonstra que of flius estava no mesmo patamar patrimonial do pater (o que poderia levar a dizer que a patria potestas, de fato, estaria extinta), mas o que não exclui a "unità economica amministrativa della famiglia":99 não, por acaso, Justiniano, em C. 3, 28, 37, 1 (=531 d.C.), denomina de peculium paganum [= "pecúlio ordinário/ comum"] aquele típico peculium concedido pelo pater, em antítese ao castrense e quasi castrense.

ca los dueños dellas pueden facer destos bienes atales lo que quiseren, et non han derecho en ellas, nin gelas pueden embargar padre, nin hermano nin otro pariente que hayan." Discurso que continua em Siete Partidas $4,17,7$, in fine: “(...) et tales ganancias como estas son quitamiente de aquellos á qui las fecieron, asi como desuso deximos."

95 Cf. VOLTERRA, Edoardo. Famiglia. cit. (nota 15), p. 742. No mesmo sentido; GUARINO, Antonio. Diritto privato romano. cit. (nota 1), p. 543-546 (=§ 40).

"Paganum", neste sentido, une os dois peculia extremos (posição jurídica do pater e do filius muda em ambos, bem como com quem está a administratio), mas por oposição ao que fosse adquirido no serviço militar e, depois, nas atividades profissionais, que se tornam, ao menos terminologicamente, os peculia mais característicos.

96 BONFANTE, Pietro. Corso di Diritto Romano. cit. (nota 21), p. 119-121.

97 BONFANTE, Pietro. Corso di Diritto Romano. cit. (nota 21), p. 120-121. Retoma a teoria que MANDRY, Gustav. Das gemeine Familiengüterrecht mit Ausschluss des ehelichen Güterrechtes. Tübingen: Laupp, 187. v. 1, p. 28 (= § 4), resume logo no início de sua obra: "Die Vermögensunfähigkeit der Hauskinder hat ihren Grund zwar nicht in dem Anspruche des Hausvaters auf den Erwerb der Hauskinder, wohl aber in der Existenz der väterlichen Gewalt und lediglich in ihr." Em outras palavras, a existência do filius sem patromonium não é decorrente de sua condição natural, mas sim daquela jurídica, ou seja, a "Vermögenslosigkeit", "ausência de patrimônio", decorre da "Vermögensunfähigkeit", "incapacidade patrimonial".

98 BONFANTE, Pietro. Corso di Diritto Romano. cit. (nota 21), p. 132. O que também não ocorreria nem com o peculium castrense, segundo este autor, uma vez que não existe sucessão legítima do pater quanto ao peculium. Sobre o retorno iure peculii, cf. Pomp. 2 sen. consul., D. 38, 17, 10.

99 BONFANTE, Pietro. Corso di Diritto Romano. cit. (nota 21), p. 138. Mesmo que o papel do peculium profecticium tenha sido abreviado em importância apenas para os escravos e na determinação da responsabilidade do pater pelos débitos sobre este peculium. 
Uma unidade patrimonial de um grupo, mantida como forma de coesão social. Afinal, a família é o "seminarium rei publicae". ${ }^{100}$

Belém, 01 de setembro de 2011.

\section{Referências}

ALBERTARIO, Emilio. Sulla "libera administratio peculii”. Rendiconti del Reale Istituto Lombardo di Scienze e Lettere, Milano, v. 61, p. 833-849, 1929.

AMIRANTE, Luigi. Lavoro di giuristi sul peculio - Le definizioni da Q. Mucio a Ulpiano. In: Studi in Onore di Cesare Sanfilippo. Milano: Giuffrè, 1983. v. 3, p. 3-15.

ARCHI, Gian Gualberto. In tema di peculio quasi castrense. In: Studi di Storia e Diritto in Onore di Enrico Besta per il XL Anno del Suo Insegnamento. Milano: Giuffrè, 1939. v. 1, p. 119-136.

BELLOMO, Manlio. Famiglia (diritto intermedio). Enciclopedia del Diritto, Milano, v. 16, p. 744$778,1967$.

BERGER, Adolf. Encyclopedic Dictionary of Roman Law. Clark: Lawbook, 1953. p. 333-772.

BESELER, Gerhard. Beiträge zur Kritik der römischen Rechtsquellen. Tübingen: MOHR, 1920. v. 4.

. Textkritische Studien. Zeitschrift der Savigny-Stiftung für Rechtsgeschichte - Romanistische Abteilung, Weimar, v. 53, p. 1-63, 1933.

BONFANTE, Pietro. Corso di diritto romano - diritto di famiglia. Milano: Giuffrè, 1963. v. 1.

. Notas a Glück C. F., Ausführliche Erläuterung der Pandecten nach Hellfeld: ein Commentar, trad. em ital., Commentario alle Pandette tradotto ed arricchito di copiose note e confronti col Codice Civile del Regno d'Italia. Milano: Libraria, 1907. v. 14 e 15, p. 1-222.

BRINZ, Alois. Lehrbuch der Pandekten. 2. ed. Erlangen: Deichert, 1886. v. 3.

BUONAMICI, Francesco. Dell'ordine dei titoli delle Pandette (Dal lib. I al lib. XXV). Pisa: Vannucchi, 1906. v. 1.

BURDESE, Alberto. Considerazioni in tema di peculio c.d. profettizio. In: Studi in Onore di Cesare Sanfilippo. Milano: Giuffrè, 1982. p. 71-111.

100 Cic. Off. 1, 54: "Nam cum sit hoc natura commune animantium, ut habeant libidinem procreandi, prima societas in ipso coniugio est, proxima in liberis, deinde una domus, communia omnia; id autem est principium urbis et quasi seminarium rei publica (...)" (= "Já que é por natureza comum de todas as criaturas vivas ter o instinto reprodutivo, a primeira união é aquela propriamente entre marido e esposa; a segunda, entre pais e crianças; em seguida, uma casa, com tudo em comum; e isto é o princípio da cidade e, por assim dizer, a origem da República"). 
CAPOGROSSI COLOGNESI, Luigi. Max Weber e le economie del mondo antico. Roma: Laterza, 2000.

. Patria potestà (diritto romano). Enciclopedia del Diritto, Milano, v. 32, p. 242-249, 1982.

CICCARELLO, Sebastiano. Patria potestà (diritto privato). Enciclopedia del Diritto, Milano, v. 32, p. $255-263,1982$. .

COSTA, Emilio. Le azioni exercitoria e institoria nel diritto romano. Parma: Battei, 1891.

DI PORTO, Andrea. Impresa collettiva e schiavo 'manager' in Roma antica (II sec. a.C. - II sec. d.C.). Milano: Giuffrè, 1984.

ERNOUT, Alfred; MEILLET, Antoin. Dictionnaire étymologique de la langue latine - Histoire des mots. 4. ed. Paris: Klincksieck, 1979.

FITTING, Hermann. Das Castrense Peculium in seiner Geschichtlichen Entwicklung und heutigen gemeinrechtlichen Geltung (1871). Amsterdam: Scientia, 1969.

FUMAGALLI, Marcella Balestri. Persone e famiglia nel diritto romano. Digesto delle Discipline Privatistiche - Sezione Civile, Torino, v. 13, p. 444-457, 1995.

GAUDEMET, Jean. Droit privé romain. Paris: Montchrestien, 1998.

GLÜCK, Christian Friedrich. Ausführliche Erläuterung der Pandecten nach Hellfeld: ein Commentar. Erlangen: Palm, 1800. v. 2.

. Ausführliche Erläuterung der Pandecten nach Hellfeld: ein Commentar. Erlangen: Palm, 1813. v. 14.

GUARINO, Antonio. Diritto privato romano (1971). 12. ed. Napoli: Jovene, 1988.

HEINRICHS, Johannes. Peculium. Der neue Pauly - Enzyklopädie der Antike, Weimar, v. 9, 2000.

HEUMANN, Hermann Gottlieb; SECKEL, Emil. Handlexikon zu den Quellen des römischen Rechts. 9. ed. Jena: Fischer, 1907.

KASER, Max. Das Römische Privatrecht - Das altrömische, das vorklassische und klassische Recht. 2. ed. München: Beck, 1971. v. 1.

. Das Römische Privatrecht - Der altertumswissenschaft. 2. ed. München: Beck, 1975. v. 2.

KELLER, Friedrich Ludwig von. Pandekten. Leipzig: Tauchnitz, 1861.

LANFRANCHI, Fabio. Il diritto nei retori romani - Contributo alla storia dello sviluppo del diritto romano. Milano: Giuffrè, 1938.

LA ROSA, Francia. I peculii speciali in diritto romano. Milano: Giuffrè, 1953.

LENEL, Otto. Das Edictum Perpetuum - Ein Versucht zu seiner Wiederherstellung (1883). 3. ed. Amsterdam: Scientia, 1985. 
LENORMANT, François. Pecunia. In: DAREMBERG, Charles; SAGLIO, Edmond (Org.). Dictionnaire des Antiquités Grecques et Romaines. Graz: Akademische, 1963. t. 4, p. 369-370.

LEVY, Ernst; RABEL, Ernest (Org.). Index Interpolationum quae in Iustiniani Digestis inesse dicuntur - Ad libros digestorum I - XX pertinens. Weimar: Böhlau, 1929. t. 1, p. 2-402.

LONGO, Giannetto. Appunti critici in tema di peculio. Studia et Documenta Historiae et Iuris, Roma, v. 1, 1935.

. Il concetto classico e il concetto giustinianeo di «administratio peculii ». Archivio Giuridico “Filippo Serafini”, Modena, v. 100, 1928. p. 184-220.

. Libera administratio peculii - I limiti e lo spirito di una innovazione giustinianea. Bullettino dell'Istituto di Diritto Romano, Roma, v. 38, p. 29-52, 1930.

MANDRY, Gustav. Das gemeine Familiengüterrecht mit Ausschluss des ehelichen Güterrechtes. Tübingen: Laupp, 187. v. 1.

. Das gemeine Familiengüterrecht mit Ausschluss des ehelichen Güterrechtes. Tübingen: Laupp, 1876. v. 2.

MARRONE, Matteo. Istituzioni di diritto romano (1989). 2. ed. Firenze: Palumbo, 1994.

MICOLIER, Gabriel. Pécule et capacité patrimoniale - Étude sur le pécule, dit profectice, depuis l'édit “de peculio" jusqu'à la fin de l'époque classique. Lyon: BOSC, 1932.

Monier, Raymond. Manuel élémentaire de droit romain - Les obligations. 4. ed. Paris: Montchrestien, 1948. v. 2.

ALVES, José Carlos Moreira. Direito romano - instituições de direito romano - parte especial direito das obrigações - direito de família - direito das sucessões (1965). 6. ed. Rio de Janeiro: Forense, 2005. v. 2.

PESARESI, Roberto. Ricerche sul peculium imprenditoriale. Bari: Cacucci, 2008.

RODGER, Alan Ferguson. Peculium. The Oxford Classical Dictionary. 3. ed. London: Oxford University, 2003.

SCHWARZENBERG, Claudio. Patria potestà (diritto intermedio). Enciclopedia del Diritto, Milano, v. 32, p. 249-255, 1982.

SCHULTING, Anton. Notae ad Digesta seu Pandectas. Lyon: Luchtmans, 1820. t. 3.

SERRAO, Feliciano. Impresa e responsabilità a Roma nell'età commerciale - Forme giuridiche di un'economia-mondo. Pisa: Pacini, 1995.

SOLAZZI, Siro. Sul peculium nell'actio de in rem verso. Archivio Giuridico "Filippo Serafini", Modena, v. 152, p, 3-18, 1957.

SOUBIE, André. Recherches sur les origines des rubriques du Digeste. Tarbes: Saint-Joseph, 1960. 
STUMPF, Gerd. Pecunia. Der neue Pauly - Enzyklopädie der Antike, Weimar, v. 9, 2000.

TALAMANCA, Mario. Istituzioni di diritto romano. Milano: Giuffrè, 1990. . In tema di azioni di arricchimento. Archivio Giuridico "Filippo Serafini”, Modena, v. 146, p. 33-74, 1954.

. Lo schema 'genus-species' nelle sistematiche dei giuristi romani, in La filosofia greca ed il diritto romano. In: Colloquio italo-francese. Roma: Accademia Nazionale dei Lincei, 1977. v. 2.

THOMAS, Yan. Droit domestique et droit politique à Rome - Remarques sur le pécule et les honores des fils de famille. Mélanges de l'École Française de Rome - Antiquité, Roma, v. 94, p. 527-580, 1982.

TUHR, Andreas von. Actio de in rem verso zugleich ein Beitrag zur Lehre von der Geschäftsführung. Freiburg: Akademische, 1895.

UXKULL-GYLLENBAND, Woldemar Graf von. Peculium. Paulys - Wissowa Realencyclopädie der classischen Altertumswissenschaft, Weimae, Stuttgart, v. 19-1, p. 13-16, 1937.

VACCARI, Pietro. Famiglia (diritto intermedio). Novissimo Digesto Italiano, Torino, v. 7, p. 46-48, 1981.

Volterra, Edoardo. Famiglia (diritto romano). Enciclopedia del Diritto, Milano, v. 16, p. 723-743, 1967.

WESENER, Gunter. Peculia - Bona adventicia - Freies und unfreies Kindesgut. In: Ivris Vincvla Studi in onore di Mario Talamanca. Napoli: Jovene, 2001. v. 8, p. 393-419.

WINDSCHEID, Berhard. Lehrbuch des Pandektenrechts. 8. ed. Frankfurt: Loening, 1901. v. 3. 